\title{
Pelatihan Pembelajaran Daring Berbasis Zoom untuk Guru MA NW Kabar Kabupaten Lombok Timur
}

\author{
Alpiana Hidayatulloh*, Khairul Rijal, Indah Arry Pratama, Bq. Malikah, Hr \\ Program Studi Teknik Sipil, Fakultas Sains, Teknik dan Terapan \\ Universitas Pendidikan Mandalika \\ *Corresponding Author: Alpianahidayatulloh11@gmail.com
}

\begin{abstract}
This community service aims to provide training on the use of the zoom application as a medium for carrying out the online learning process, this training was attended by MA NW Kabar teachers, Sakra District, East Lombok Regency. In this training the community service implementation team collaborates with information and computer engineering teachers. The training method used is direct training using the instruments provided after the training. The target achieved after this training is the understanding of the teacher using the zoom application as an online learning medium. As a result of this training, $80 \%$ of teachers in each subject use zoom as a medium to carry out the learning process online.
\end{abstract}

Abstrak: Pengabdian kepada masyarakat ini bertujuan untuk memberikan pelatihan penggunaan aplikasi zoom sebagai media untuk melakukan proses pembelajaran daring. Pelatihan ini diikuti oleh guru MA NW Kabar Kecamatan Sakra Kabupaten Lombok Timur. Dalam pelatihan ini tim pelaksana pengabdian bekerja sama dengan guru teknik informasi dan komputer. Adapun metode pelatihan yang digunakan adalah dengan cara pelatihan secara langsung dengan menggunakan instrumen yang diberikan setelah pelatihan. Target yang dicapai setelah pelatihan ini adalah pemahaman guru menggunakan aplikasi zoom sebagai media pembelajaran daring. Adapaun hasil dari pelatihan ini adalah $80 \%$ guru disetiap mata pelajaran menggunakan zoom sebagai media untuk melakukan proses pembelajaran secara daring.

\section{Article History:}

Received: 12-03-2021

Reviewed: 14-04-2021

Accepted: 24-04-2021

Published: 05-05-2021

Key Words:

Training, Zoom

Application Training, Online.

Sejarah Artikel:

Diterima: 12-03-2021

Direview: 14-04-2021

Disetujui: 24-04-2021

Diterbitkan: 05-05-2021

\section{Kata Kunci:}

Pelatihan Aplikasi Zoom, Daring.

How to Cite: Hidayatulloh, A., Rijal, K., Pratama, I., \& Malikah, Hr, B. (2021). Pelatihan Pembelajaran Daring Berbasis Zoom untuk Guru MA NW Kabar Kabupaten Lombok Timur. Jurnal Pengabdian UNDIKMA, 2(1), 115-119. doi:https://doi.org/10.33394/jpu.v2i1.3581

doi:https://doi.org/10.33394/jpu.v2i1.3581

This is an open-access article under the CC-BY-SA License.

\section{Pendahuluan}

Indonesia saat ini mengalami sebuah krisis kesehatan karena indonesia mengalami sebuah wabah penyakit yang disebabkan oleh virus, dimana virus ini membuat masyarakat tidak memiliki ruang gerak yang luas karena penyebarannya sangat cepat virus tersebut disebut virus Covid-19 atau virus corona. Virus corona merupakan salah satu jenis virus yang menyerang sistem pernapasan manusia dan menyebabkan kematian. Menurut WHO virus corona merupakan virus yang menyebabkan penyakit pada hewan dan manusia yang menyebabkan infeksi pada pernafasan mulai dari flu hingga penyakit yang lebih parah. Virus ini menyerang manusia dengan sangat cepat apabila terjadi kontak dengan orang yang terpapar virus.

Seperti di negara-negara lainnya kasus Covid-19 di indonesia juga semakin meningkat dengan aktivitas masyarakat, Berdasarkan laporan Kemenkes RI, pada tanggal 30 Agustus 2020 tercatat 172.053 kasus konfirmasi dengan angka kematian 7343 (CFR 4,3\%). DKI Jakarta memiliki kasus terkonfirmasi kumulatif terbanyak, yaitu 39.037 kasus. Daerah dengan 
kasus kumulatif tersedikit yaitu Nusa Tenggara Timur dengan 177 kasus (Kemenkes RI, 2020).

Dengan meningkatnya kasus Covid-19 pemerintah melakukan berbagai upaya pencegahan salah satu adalah dengan melakukan sosial distancing. Dilangsir dari the Washington post, Kamis (26/3/2020) profesor ilmu politik di Northeastern University Daniel Aldrich menjelaskan bahwa sosial distancing merupakan salah satu upaya memperlambat penyebaran virus corona. Sehingga perlu diterapkan di indonesia karena kasus Covid-19 yang semakin meningkat. Sosial distancing berlaku disemua sektor pemerintah salah satunya pada sektor pendidikan yaitu proses belajar mengajar disekolah ditiadakan. Sehingga pemerintah khususnya menteri pendidikan mengambil langkah bagaimana akar sektor pendidikan tetap terlaksana ditengah wabah virus corona.

Upaya pemerintah agar terlaksananya proses pembelajaran adalah dengan pembelajaran jarak jauh atau pembelajaran online atau lebih dikenal dengan pembelajaran daring. Menteri Nadiem Anwar Makarim menerbitkan Surat Edaran Nomor 3 Tahun 2020 pada Satuan Pendidikan dan Nomor 36962/MPK.A/HK/2020 tentang Pelaksanaan Pendidikan dalam Masa Darurat Coronavirus Disease (Covid-19) maka kegaiatan belajar dilakukan secara daring (online) dalam rangka pencegahan penyebaran coronavirus disease (Covid-19) (Menteri Pendidikan, 2020).

Pembelajaran daring merupakan pembelajaran yang dilakukan secara online dengan menggunakan aplikasi teknologi digital yang membantu proses pembelajaran. Menurut Bonk Curtis J (2002) pembelajaran online (daring) merupakan interaksi guru dan siswa jarak jauh dengan bantuan teknologi informatika. Pembelajaran daring dengan aplikasi teknologi informasi bersifat fungsional sehingga peserta didik memiliki keleluasan watu untuk belajar dan dapat belajar kapanpun dan dimanapun tanpa dibatasi ruang dan waktu. Seperti yang telah disampaikan oleh Keengwe \& Georgina dalam penelitiannya telah menyatakan bahwa perkembangan teknologi memberikan perubahan terhadap pelaksanaan pengajaran dan pembelajaran (Keengwe \& Georgina, 2012). Teknologi informasi dapat diterima sebagai media dalam melakukan proses pendidikan, termasuk membantu proses belajar mengajar, yang juga melibatkan pencarian referensi dan sumber informasi (Wekke \& Hamid, 2013). Pada pembelajaran daring peserta didik dapat berinteraksi dengan guru dengan menggunakan video call atau live chat melalui berbagai aplikasi android seperti what's up, zoom, classroom dan lain-lain.

Aplikasi tersebut mungkin masih asing disebagian kalangan termasuk guru, sehingga tidak bisa menggunakan aplikasi tersebut dengan baik sedangkan guru dituntut untuk bisa menggunakan berbagai aplikasi online tersebut hal itu juga terjadi pada guru di MA NW Kabar Kecamatan Sakra Kabupaten Lombok Timur. Banyak dari guru MA NW Kabar tidak bisa menggunakan aplikasi tersebut sehingga guru mengalami hambatan dalam melakukan pembelajaran daring. Sehingga kami melakukan pelatihan bagi guru MA NW Kabar penggunaan aplikasi- aplikasi tersebut salah satunya yaitu zoom. Zoom merupakan aplikasi komunikasi yang berbasis video dan bisa diakses via android dan website sehingga memudahkan para penggunanya untuk menggunakannya di smartphone ataupun lewat komputer. Sehingga Zoom dapat dijadikan salah satu aplikasi yang bisa digunakan untuk melakukan proses pembelajaran secara daring karena selain menggunakan video zoom juga menggunakan audio sehingga dengan aplikasi zoom siswa dapat menyaksikan dan mendngarkan langsung ketika proses pembelajaran berlangsung, sehingga sangat efektif dijadikan sebagai media pembelajaran. Tetapi banyak dari guru termasuk guru MA NW Kabar Kecamatan Sakra Kabupaten Lombok Timur tidak dapat menggunakan aplikasi 
tersebut, sehingga dalam hal ini pelaksana akan memberikan pelatihan penggunaan aplikasi zoom kepada guru MA NW kabar sehingga bisa digunakan sebagai media pembelajaran daring.

\section{Metode Pengabdian}

Pelatihan dilakukan di MA NW Kabar. pelatihan ini bertujuan untuk memberikan pelatihan kepada guru MA NW kabar dalam penggunaan aplikasi zoom sebagai media pembalajaran daring. Metode pelatihan dengan menggunakan pelatihan langsung kemudian selama proses pelatihan pelaksana mengukur pemahaman guru untuk menggunakan aplikasi zoom. Peserta dalam pelatihan ini adalah 18 orang guru sekolah MA NW kabar. Perlengkapan yang dibutuhkan selama proses kegiatan disiapkan oleh pelaksana dan mitra diantaranya adalah tempat kegiatan, konsumsi dan LCD. Adapun teknik pelaksanaanya adalah :

1) mengatur jadwal dan tempat pelaksaan pelatihan, adapaun jadwal pelatihan dapat dilihat pada tabel 1

Tabel 1. Jadwal pelatihan penggunaan aplikasi zoom

\begin{tabular}{|l|l|}
\hline \multicolumn{1}{|c|}{ Jam } & \multicolumn{1}{|c|}{ Kegiatan } \\
\hline $08.00-08.30$ & Persiapan \\
\hline $08.35-08.50$ & Pembukaan dan do'a bersama \\
\hline $09.00-10.30$ & Pelaksanaan pelatihan \\
\hline $10.35-12.00$ & Diskusi bersama \\
\hline $12.00-12.30$ & Penutup \\
\hline
\end{tabular}

2) menyiapkan alat dan bahan yang dibutuhkan dalam pelatihan

3) menjelaskan kepada guru langkah- langkah penggunaan zoom dengan LCD yang sudah disiapkan mitra.

4) Evaluasi kegiatan

\section{Hasil Pengabdian dan Pembahasan}

Kegiatan pelatihan ini dilaksanakan karena banyak keluhan guru terhadap metode pembelajaran dengan menggunakan aplikasi WA yang kurang efektif terutama pada mata pelajaran MIPA, sehingga dengan kesepakatan guru-guru MA NW Kabar Kecamatan Sakra Kabupaten Lombok Timur untuk menggunakan aplikasi lain yang lebih efektif dan dapat melakukan proses pembelajaran secara langsung yaitu salah satunya dengan menggunakan aplikasi zoom. Hal itu sesuai dengan pendapat Iskandarwassid dan Sunendar (2011) bahwa Aplikasi zoom merupakan metode yang mengajarkan bahasa dengan memanfaatkan alat pandang dengar, seperti video, karti, tape recorder atau prgram telivisi sehingga pengajaran manjadi lebih hidup dan menarik. Sehingga dapat dikatakan bahwa aplikasi zoom sangat membantu proses pembelajaran secara daring karena aplikasi zoom memiliki fungsi untuk komunikasi menggunakan video dan audio melalui jaringan internet sehingga dapat disaksikan langsung oleh siswa.

Kegiatan pelatihan ini melibatkan semua guru dengan persetujuan dan dukungan dari kepala madrasah. Adapun tujuan dari pelatihan ini adalah untuk memberikan pelatihan kepada guru MA NW Kabar Kecamatan Sakra Kabupaten Lombok Timur mengenai penggunaan zoom sebagai media dalam pelaksanaan proses pembelajaran secara daring. Adapun jenis kegiatan pelatihan yang dilakukan adalah sebagai berikut:

1) Bagaimana membuat akun zoom 
2) Bagiamana menginvite( mengundang) siswa untuk masuk ke dalam akun zoom masingmasing guru

3) Bagaimana menampilkan materi baik berupa powerpoint,dokumen ataupun pdf kepada siswa pada aplikasi zoom

4) Bagaimana teknis ketika proses pembelajaran berlangsung dengan menggunakan zoom Adapun bentuk kegiatannya dapat dilihat pada gambar berikut:
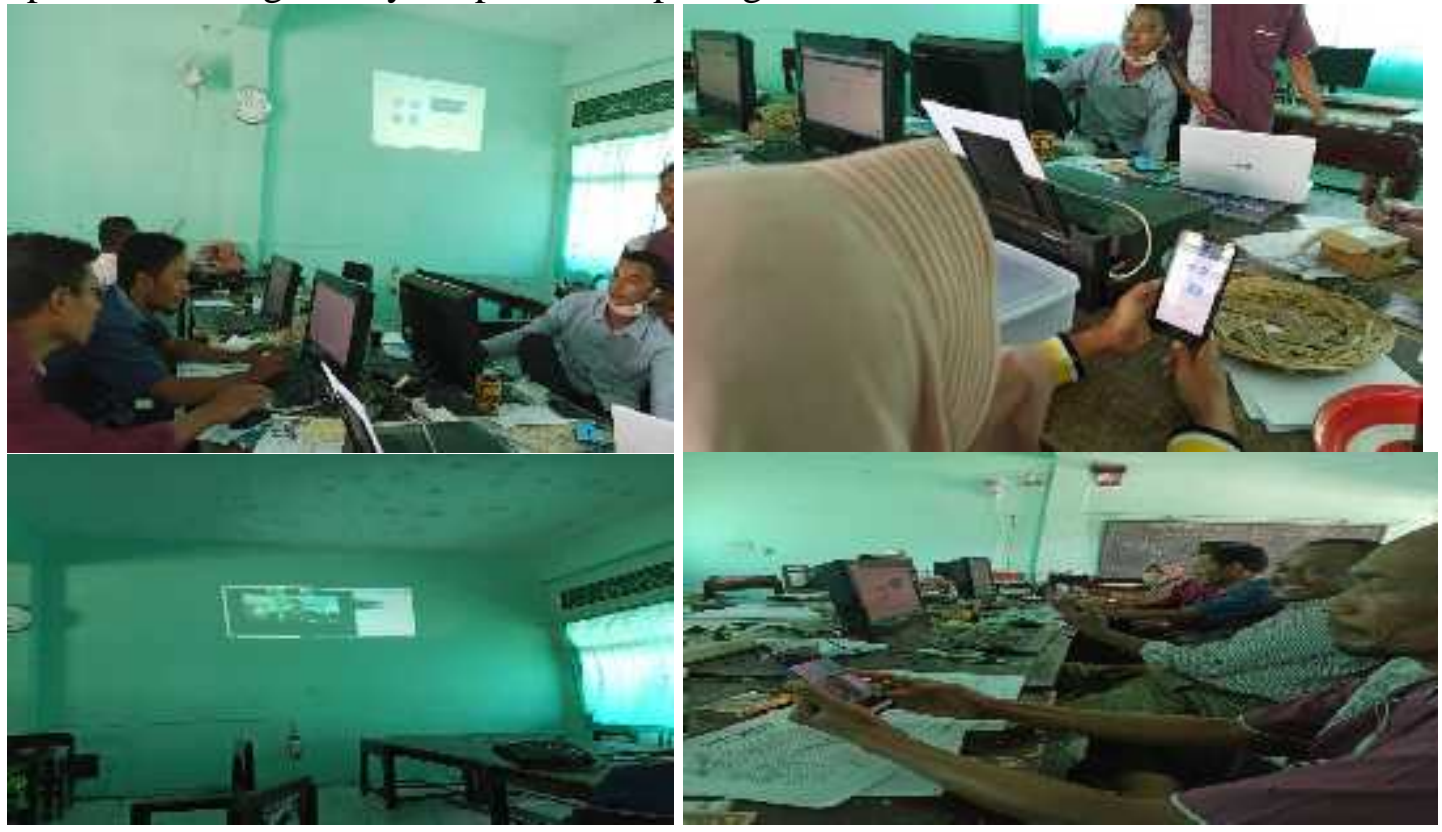

Gambar 1. Aktivitas Pelatihan Pembelajaran daring Berbasis Zoom

Sehingga setelah pelatihan $80 \%$ guru menggunakan aplikasi zoom untuk melakukan proses pembelajaran walaupun dalam proses pelaksanaan pembelajaran tidak semua siswa menggunakan zoom karena alat penunjang yang tidak memadai. Dengan menggunakan aplikasi zoom, guru menjadi lebih aktif dalam menyiapkan materi ajar baik dengan menggunakan video, word, $p d f$ maupun powerpoint.

\section{Kesimpulan}

Kesimpulan yang dapat diambil dari kegiatan pengabdian ini antara lain adalah;

1) Guru membutuhkan media pembelajaran secara daring yang dapat menunjang pelaksanaan proses pembelajaran

2) Dengan pelatihan penggunaan aplikasi zoom, guru mengatahui penggunaan aplikasi zoom sebagai media proses pembelajaran secara daring

3) Aplikasi zoom sangat membantu guru dalam melaksanakan proses pembelajaran

\section{Saran}

Adapun saran dalam pelaksanaan kegiatan ini adalah agar pelatihan lebih sering dilakukan pelatihan untuk guru dalam pelaksanaan pembelajaran secara daring dengan menggunakan berbagai aplikasi online. 


\section{Daftar Pustaka}

Atmadani, R., \& Hidayati, I. (2020). Pelatihan Apoteker Cilik dan DaGuSiBu bagi Siswa SDN Losari di Singosari, Kabupaten Malang. Jurnal Pengabdian UNDIKMA, 1(2), 7781. doi:https://doi.org/10.33394/jpu.v1i2.2966

Firman. (2020). Pembelajaran Online di Tengah Pandemic Covid - 19. Indonesian Journal of Educational Science. 2(2)

Efendi, I., Safnowandi, S., Dewi, I., Utami, S., \& Abidin, Z. (2020). Pelatihan Produk Olahan Jamur Pasca Panen untuk Penguatan Produktivitas Ekonomi SMA Islam Al-Azhar NW Kayangan. Jurnal Pengabdian UNDIKMA, 1(2), 100-105. doi:https://doi.org/10.33394/jpu.v1i2.2876

Putra, Nugraha Permana. (2020). Solusi Pembelajaran Jarak jauh Menggunakan Aplikasi Zoom dan Whatsapp Group di Era New Normal Pada Warga Belajar Paket C di Pusat Kegiatan Belajar Masyarakat (PKMB) Bina Insani. JIPSINDO. 2(7)

Sobron, A, Bayu, Rani, \& Meidawati. (2019). Persepsi Siswa Dalam Studi Pengaruh Daring Learning Terhadap Minat Belajar IPA. SCAFFOLDING: Jurnal Pendidikan Islam Dan Multikulturalisme.

Solihin, Ahmad. (2020). Pembelajaran Online dengan Aplikasi Zoom Meeting di Kelas 5 SDN 1 Selaawi di Masa Pendemi Covid - 19. Jurnal Kehumasan. 3(2)

Suhery. (2020). Sosialisasi penggunaan Aplikasi Zoom Meeting dan Google Classroom Pada Guru di SDN 17 Mata Air Padang Selatan. Jurnal Inovasi Penelitian.1(3)

Tim, C. I. (2020). Corona, Kelas Daring, dan Curhat 2 Guru untuk Orang Tua. CNN Indonesia.https://m.cnnindonesia.com/gayahidup/20200330165053-284488368/coronakelas-daring-dan-curhat-2-guru-untuk-orangtua. 